\title{
Realization of author's program of developing artistic abilities of schoolchildren on basis of continuity
}

\author{
D.V. Legenchuk ${ }^{1 *}$ \\ ${ }^{1}$ Federal state budgetary educational institution of higher education "Kurgan state University", \\ Kurgan, Russia
}

\begin{abstract}
The definition of abilities and their correct development act as one of the most important pedagogical tasks that require special attention, solution, approach, especially during the period of changes in the content of the educational process connected with its reform. According to the author, to update educational approaches related to improving the effectiveness of the educational process, it is necessary to pay attention to the development of author's training programs. They will control planned and systematic activities of all participants in the educational process, regardless of the form of its organization. The article considers the main provisions of the author's program that contribute to the development of the artistic abilities of schoolchildren in the conditions of modernization and reform of modern Russian education, including the changes caused by COVID 19. The author's program is designed to expand the content of the concept of the continuity of secondary vocational and higher education. Its structure includes content components of general education and training of future designers and teachers of technology and design in multilevel professional education as potential directions for its development in the context of global challenges.
\end{abstract}

\section{A problem statement}

The reform of the modern system of Russian education, at all its levels, primarily forces us to look for new ways and forms of using the personal potential of students. We developed and successfully implemented a model of continuity of secondary vocational and higher education, in which great attention was paid to the development of educational abilities of college and university students. However, the further realization of the model within the framework of a multi-level educational complex based on continuity, has shown that for its successful development, it is necessary to expand it and include supplementary educational institutions into this complex. This necessity was conditioned by a low level of training of applicants of creative majors. For their further training in specialized disciplines, it was necessary to start this training from scratch. This was especially a matter of the specialties "Teacher of Drawing" and "Design". The students of the first courses of integrated

* Corresponding author: prof-ped.gpa@mail.ru 
specialties of the college and university absolutely did not have graphic skills and artistic abilities in these areas. We decided to organize professional orientation and preliminary selection of students of 6-8 forms of the school, studying art specialties at creative school [1]. Initially, 100 students were selected. The initial diagnosis allowed us to identify the insufficient level of development of artistic abilities in students who were chosen to participate in the experiment. This fact proved the necessity to implement the developed author's concept, process model and pedagogical conditions, aimed at the successful development of artistic abilities in the process of continuous interaction in a multi-level educational complex.

\subsection{The objective of the work}

The purpose of our experiment is to implement the model of the process of developing the artistic abilities of schoolchildren, which is worked out taking into account three approaches: systemic, continuous and systemic-active.

In accordance with the objectives of the study, the author's integrated class-studio program "Basic master skills" was developed on the basis of the continuous interaction of art schools, college and university. The program is realized in two directions:

- $\quad$ artistic and aesthetic: developing artistic abilities, cultivating artistic taste;

- $\quad$ cultural: study of different styles, directions, genres, fine arts.

The presented content of the integrated program contributes to the development of the artistic abilities of students thanks to:

- development of students' ideas about genres and types of art, their figurative language;

- use of tasks aimed at studying and practical mastering of art techniques and materials.

Due to its content, the author's program ensured "cross-cutting" lines that help to improve the students' understanding of genres and types of art, their figurative language. Practical tasks were aimed at studying and practical mastering of all traditional art techniques and materials (graphic, art, sculptural) [2].

The peculiarity of the author's program is its focus on the content of general and secondary vocational education (opportunities for individual development of those abilities that are not always developed in the educational process of a general education school), as well as its emotional intensity (opportunities of solving the problem of social adaptation and professional self-determination).

The achievement of the planned results was determined by the identified components of the development of artistic abilities (artistic-cognitive, emotional, strong-willed, visualanalytical, sensorimotor, artistic-active) [3].

The level of effectiveness of the developed program was evaluated according to two criteria:

- $\quad$ results of artistic activities in the form of exhibitions of children's creativity;

- results of participation of students of control and experimental groups in creative competitions of different levels.

Realized on the basis of general education, the school module was developed on the ground of several regulatory documents: the Law of the Russian Federation "On education in the Russian Federation", the Federal component of state standards of general, the model program of general education in fine arts, the author's program by B.M. Nemenskiy "Fine arts and art work" for 1-9 forms, a federal list of textbooks recommended by the Ministry of education and science of the Russian Federation. 


\section{Results of the research}

The study of the educational subject "Fine arts" takes place in class (the main form of work) in the 6th form and 34 training hours are due: 1 hour a week. This stage involves the study of easel, fine arts, the formation of the basics of literacy of the artistic image (drawing, painting, sculpture), the understanding of the basics of the visual language, the specifics of art types. In connection with age characteristics, students of the 6th form begin to develop critical perception of their work from professional point of view. If there is a desire to master the skills of a realistic image and if there is no fear, it is possible to intensify the development of artistic abilities according to age level.

The school year is divided thematically and is based on the genre principle: each genre is considered in its historical development. The skills and practical experience of drawing, color, form, space are developed gradually according to the specifics of the figurative system of a particular type and genre of fine arts $[4,5,6]$.

At the end of teaching fine arts, in independent creative activity, 6th form students:

- know the main types and genres of fine arts, outstanding representatives of domestic and foreign art and their main works;

- master the basics of image understanding (color, tint, coloration, proportions, light-and-shade, perspective, space, volume, composition);

- $\quad$ use artistic and expressive means of graphics, painting, sculpture;

- $\quad$ analyze the content, figurative language of works of different types and genres of fine arts; recognize the studied works;

- $\quad$ use artistic materials (gouache, watercolor, ink, simple pencil, plasticine);

- use the means of artistic expressiveness (line, color, tint, volume, light, perspective, composition).

The second module, which is being realized on the basis of supplementary education, was drawn up in accordance with the Law of the Russian Federation "On education in the Russian Federation", the Decree of the President of the Russian Federation "On the national strategy of activities to the benefit of children for 2012-2017," a letter on approximate requirements to the programs of departments of supplementary education of children (Ministry of education and science of the Russian Federation, department of youth policy, education and social protection of children dated 11.12.2006, No. 06-1844), sanitary and epidemiological requirements to institutions of supplementary education of children, sanitary-epidemiological rules 2.4.4.1251-03 (introduced 20.06.2003, No. 27D). The use of this integrated programme at the formative stage has increased the opportunities of departments of supplementary education of children and schools. The program has helped to solve the problem of developing artistic abilities of schoolchildren.

Training of the second module lasts for 1 year (144 hours). Classes are held 2 times a week for 2 hours.

Since the number of hours in this module has been increased by 4 times compared to school, it is necessary to create all the necessary conditions for classes at an increased level. All the applicants are included into the group. The content of the module is based on the content of basic general education, which contributes to the individual progress of artistic abilities, which are not always developed in the educational process of a secondary general school. The thematic division of the school year corresponds to the topics of the first module of the general education. At the age of 11-15 years old, adolescents have a strong desire to analyze and gain knowledge and skills of realistic portrayal of reality. That is why the program under consideration aims at providing deeper ideas about the main genres and types of fine arts, at teaching the figurative language of the image. It pays attention to representing form, proportions, volume, perspective, photography, composition in drawings. Students get acquainted with the types and genres of fine arts in the process of 
creative activity, the purpose of which is to realize their own ideas in specific artistic material, in each of the types of artistic activity [7].

Training is a set of the educational-cognitive, art-developing, control-diagnostic classes (Table 1). Their peculiarity is that they are aimed at stimulating activity and students' interest in developing their own artistic abilities.

Table 1. Forms of educational classes for development of artistic abilities in the supplementary education of children.

\begin{tabular}{|l|l|}
\hline \multicolumn{1}{|c|}{ Target } & $\begin{array}{l}\text { Forms of educational classes in institutions of } \\
\text { supplementary education of children }\end{array}$ \\
\hline Educational-cognitive & $\begin{array}{l}\text { Lectures, museum classes, round tables with } \\
\text { artists, group and individual consultations on } \\
\text { projects, excursions, discussions. }\end{array}$ \\
\hline Art-developing & $\begin{array}{l}\text { Master classes, creative workshops, plein air, } \\
\text { practical lessons. }\end{array}$ \\
\hline Control-diagnostic classes & $\begin{array}{l}\text { General and personal exhibitions, competitions of } \\
\text { different levels, quizzes, tests, project defense. }\end{array}$ \\
\hline
\end{tabular}

In the process of implementing the author's integrated program of the class-studio "Young artist", students formed practical skills and abilities in the field of image successfully, as well as they acquired theoretical knowledge of fine arts. This was achieved with the use of creative tasks, a special system of exercises for the development of imagination, fantasy, creative thinking, the integration of various types of art, work with various artistic materials; stimulating creative, research-based self-work, based on revealing the individual qualities of each child.

For example, at the lessons we offered the following exercises in order to develop the imagination of students:

- $\quad$ finding an image in spots (make color spots on wet paper with gouache so that the boundaries of the spots flow onto each other, the task is: to find a familiar image in theses spots and finish the image for everyone to understand what it is);

- $\quad$ work with ink on a wet sheet (ink drops spread out and form interesting figures; task: create a specified image or find an image in the resulting spots and finish the painting);

- $\quad$ thread painting (wet the thread with paint, put it between two sheets of paper in at random, stretch to make a dynamically smeared spot; task: find images in the spot and finish them);

- $\quad$ monotyping (make color spots on glass or polyethylene film randomly and make a print on a clean sheet; task: finish the image).

The integration of the arts greatly affects students' development of the various forms of thinking necessary for successful artistic activity. At lessons in a secondary general school and classes in the institutions of supplementary education for children as part of the implementation of the "Young artist" class-studio program, we integrated aesthetic cycle subjects - music, painting, literature. According to G.N. Dubogryzova, such a triad affects "the main spheres of a child's personality (thoughts, feelings and ideas). At the same time, a student masters three ways of familiarizing with the world (knowledge, understanding and transformation), which are due to thinking, experience, imagination [8]. Art tends to realize all these three aspects of a person's spiritual life, providing the work of thought with a word, experiences with music, and ideas with fine arts". When we study the expressive means of painting and graphics (lines, color, rhythm of color spots, volumes, symmetry and asymmetry of the composition), we compare them with musical means of expressiveness (the character of the melodic line, rhythm, tempo, harmonic and timbre colors, the structure of the form). Their similarity is observed. It determines the presence of an integrated 
approach to the study of arts. When reflecting the world, a composer, an artist, a writer and a poet think in images. Considering them in a relationship, students create a real image, fantasy and imagination are activated. Such lessons are informationally rich, since there is a constant change in the types of educational activities. To teach within the framework of the author's integrated program of the class-studio "Young artist", lessons and classes in fine arts were conducted with visual, musical and literary material on the following topics:

- landscape ("Seasons" by P.I. Tchaikovskiy, A. Vivaldi; reproductions of paintings by I. Levitan, I. Shishkin, F. Vasiliev; poems by A.S. Pushkin, S.A. Yesenin);

- illustration of the tale ("Bogatyrskaya" by A.P. Borodin; V. Vasnetsov's work "Bogatyrs"; ancient Russian bylinas about bogatyrs).

In addition, with the aim of successful development of artistic abilities of students, we paid special attention to non-traditional materials and tools to do exercises with:

- technique of painting using stiff glue brush;

- $\quad$ pointillism;

- $\quad$ engraving on cardboard;

- $\quad$ painting using dry brush;

- $\quad$ print with the help of paper.

It should be noted that the interest of schoolchildren in the subject is closely related to the quality of teaching. For the art of teaching the teacher must know the subject itself, the basic provisions of pedagogy, psychology, physiology, as well as he must understand the rules of teaching methods [9]. But the most important quality of the teacher is the ability to use all this knowledge creatively in the educational process.

In addition, according to V.S. Kuzin, to master the material well, the teacher needs to use various methods and techniques of explaining, interviewing, etc. in conducting fine art lessons. [6].

N.N. Rostovtsev believes that in teaching, as in any type of art, inspiration, intuition, resourcefulness, and creativity are necessary. "While improvising during the first chords a composer begins to create and develop a melody, look for a new, most beautiful and expressive sound. So does the teacher who begins to find new, most effective methods of presenting material" [7].

\section{Conclusions}

From the above, it can be concluded that the success of the continuous interaction of educational institutions of the development of the students' artistic abilities depends on the professionalism of teachers working in these organizations as well. To improve the quality of pedagogical work, an interdepartmental city department of fine arts was created. It includes teachers of fine arts in of Kurgan schools, teachers of supplementary education, conducting fine arts circles in various organizations, as well as teachers of the city children's art school. At the meeting of the department, master classes were held on the use of various artistic materials in class. Teachers, working on the integrated educational program of the class-studio "Young artist" showed creative reports, demo lessons and classes of fine arts. There were round tables which raised questions about the need to develop artistic abilities and early career guidance of students. Seminars and meetings on educational work and the study of the legal framework necessary for the implementation of educational work were also held.

In order to improve the skills of artistic activities at the professional level, workshops on painting, graphics, sculpture were organized and held as part of the city support platform on the basis of Children's Art School No. 1 of the city of Kurgan. To improve the quality and 
extent of theoretical knowledge of the teaching staff, the employees of this institution conducted lectures and excursions.

Thus, the main task of the developed integrated program "Young artist" is to ensure the development of the artistic abilities of students in the process of continuous interaction of general and supplementary education. Such integration can be one of the levers to modernize general education through the use of the potential of supplementary education $[10,11]$.

The second condition is the principle of continuity of general and supplementary education in the process of developing artistic abilities of students, which was realized by connecting forms, methods and means of education in these organizations.

During the experiment, the main form of work in a secondary general school was a lesson. We used various forms of classes: lectures, museum classes, master classes and round tables with artists, group and individual consultations on the creation of creative projects, excursions, conversations, creative workshops, plein air, practical classes, general and personal exhibitions, competitions of different levels, creative projects defense, quizzes.

On the basis of the Kurgan regional art museum, researchers and art historians organized:

- lectures and museum classes on the topics: "Drawing as the basis of a realistic image", "Under the sail of inspiration", "Graphic art";

- excursions "Watercolor world", "Children's image in painting";

- $\quad$ round tables: "Do the youth need a museum?" with employees of the Kurgan regional art museum, "Art and we" with the members of the Kurgan branch of the Russian association of artists - V.V. Arkhipov and M.I. Karimova;

- a series of master classes: "Drawing tropical butterflies", "I will paint a ball", "Tales of a bloomy garden" with artists E.V. Gudzenko, E.P. Arkhipova, M.I. Karimova;

- meeting with V.A. Pichugin "My Childhood House".

In teaching activities, we monitored the constant interaction of various training technologies, their reciprocal effect on the content of the lesson and classes. At this stage of the experiment, traditional pedagogical technologies (healthy-saving, personality-oriented and developmental training) were realized as well as innovative ones (method of creative and social projects, research method, museum pedagogy, training in cooperation, activity approach).

The third condition is the cooperation between organizations of general and supplementary education of children on the systemic level of organizing the process of developing artistic abilities of students. The systemic components of such interaction include the definition and comparability of the goals of educational parties, the differentiation of their powers, coordination of joint activities, resource support (regulatory, scientific and methodological, personnel, organizational, information and methodological, material, motivational) [12-14].

As part of testing the author's concept of developing artistic abilities of schoolchildren, we set a common goal for educational institutions - to develop artistic abilities of students.

It is worth noting that we have differentiated the powers between educational institutions. On the basis of secondary school No. 38 with in-depth study of some subjects, in the experimental group and control group, fine arts lessons were conducted according to the curriculum. The content of the lessons was included in module lof the integrated program of the class-studio "Young artist". In the children's activity centre "Harmony" module 2 of the integrated program of the class-studio "Young artist" was implemented. Pedagogical workers of this organization conducted classes on artistic activities, organized exhibitions of children's creativity, plein air, visits to museums, exhibition halls, meetings 
and master classes with members of the regional branch of the Russian association of artists in the experimental group.

The coordination of joint activities for the development of students' artistic abilities was implemented by the methodologist of the Kurgan city innovation and methodological center and vice principals of educational institutions.

The result of the implementation of the third pedagogical condition was:

- the development of a teaching and methodological complex of continuing pedagogical support for the development of artistic abilities of schoolchildren. It includes: a program of interaction between organizations of supplementary education of children and secondary general school; author's program of the class-studio "Young artist"; methodological recommendations to students on organizing independent work; methodological recommendations for teachers; assessment tools (tests, themes for research and creative projects); lecture notes; texts of reports and presentations on the methods of teaching fine arts, held at meetings of the city methodological associations of teachers of general education schools and teachers of organizations for supplementary education of children, at meetings of the city department of fine arts, the support platform "ABC of academic drawing".

- the set of regulatory and legal documents of the federal, regional, municipal levels that regulate the activities of the secondary general school, the organization of supplementary education of children and others, necessary in their interaction;

- the development of a boilerplate contract of cooperation between departments.

Workshops for teachers and teachers on various topics were held as a part of the systemic organization of the process of students' development of artistic abilities.

\section{References}

1. J.R. Nesterova, Pedagogical conditions for the development of creative abilities of younger schoolchildren in visual activity by means of painting, taking into account federal state requirements, Bulletin Series: Pedagogy. Psychology, 5(23) (2017)

2. S.G. Genrikhovich, Environmental approach as a pedagogical innovation and the conditions for its development, 148 (2001)

3. Yu.S. Manuylov, Conceptual foundations of the environmental approach in education, Bulletin of KSU named after N.A. Nekrasov, 14, 21-27 (2008)

4. V.A. Yasvin, Educational environment: from modeling to design, 365 (2001)

5. A.V. Ivanov, The phenomenon of the cultural environment of the educational organization in the development of spiritual values by children, Pedagogical education in Russia, 4, 198-205 (2016)

6. E.M. Dorozhkin, E.F. Zeer, Methodology of vocational and pedagogical education: theory and practice (theoretical and methodological foundations of vocational and pedagogical education), Education and Science, 9, 4-20 (2014)

7. D.V. Legenchuk, Pedagogical conditions for the succession of multilevel vocational education in the region, Problems of modern teacher education, 232-238 (2016)

8. Legenchuk E.A., D.V. Legenchuk, Some components of the multilevel vocational education management process, Continuing education in the modern world: history, problems, prospects, 162-165 (2016)

9. N.A. Moreva, Pedagogy of secondary vocational education: a textbook for students, 432 (2008) 
10. V.G. Nemirovsky, A.V. Nemirovskaya, Social competitiveness: chances of success in youth and adults, Sociological Journal, 24(2), 135-149 (2018)

11. G.F. Shafranov-Kutsev, G.Z. Efimova, The formation of competitive personality traits is the main task of the education system, Alma mater (Bulletin of higher education), 10, 69-76 (2017)

12. L.A. Shipilina, Methodology of psychological and pedagogical research, 208 (2018)

13. E.V. Romano, T.V. Drozdova, Distance learning: necessary and sufficient conditions for effective implementation, Modern education, 1, 172-195 (2017)

14. E. Lewandowska, Children's well-being and distance learning during pandemics covid-19, 5 (2020)

15. D.V. Legenchuk, T.I. Ekimova, Conceptual foundations for the development of the visual abilities of applicants based on media competence in the process of continuous interaction of educational organizations, Published by Atlantis Press SARL, 10-15 (2020)

16. D.V. Legenchuk, Educational and cognitive activity in the system of multilevel professional education in the context of continuity, Proceedings of the international scientific and practical conference on education, health and human wellbeing, 22-27 (2019)

17. D.V. Legenchuk, Peculiarities of individualization principles of multilevel professional education under conditions of the cross-border educational complex, Proceedings of the ecological-socio-economic systems: models of competition and cooperation, 56-62 (2019) 